\title{
Pereskia aculeata: biological analysis on wistar rats
}

\author{
Luciele Milani ZEM ${ }^{1 \star}$, Cristiane Vieira HELM² ${ }^{2}$ Gilberto Simeone HENRIQUES ${ }^{3}$, Daniela de Almeida CABRINI ${ }^{4}$, \\ Katia Christina ZUFFELLATO-RIBAS ${ }^{5}$
}

\begin{abstract}
Pereskia aculeata Mill., a species of the family Cactaceous, popularly known in Brazil as ora-pro-nobis, has high protein, vitamin and mineral contents. High essential amino acid concentrations should be underscored, suggesting a better evaluation of the fractions. Current study quantifies amino acid content and the chemical score (CS) of protein amino acids, determining in vivo digestibility, protein efficiency ratio (PER) and net protein ratio (NPR) of $P$. aculeata. Plant material was collected, washed, placed in an oven at $60^{\circ} \mathrm{C}$, ground and stored in a freezer for chemical analysis. Diets that maintain isoproteic and isocaloric characteristics were prepared for the bioassay, namely: casein (no protein) and Pereskia aculeata leaves-based flour. Eighteen male albino Wistar rats, divided into three experimental groups of 6 animals each, were used to evaluate protein quality and bioavailability of micronutrients. Pereskia aculeata flour provided as a single source is inadequate for growth, although it is relevant for maintaining protein metabolism indicated by net protein ratio (2.87). It is actually a good quality protein source due to few limiting essential amino acids, and it meets the diet requirements for humans.
\end{abstract}

Keywords: Ora-pro-nobis; protein quality; digestibility; PER; NPR; PDCAAS.

Practical Application: Pereskia aculeata when provided as a single source is not adequate for proper growth, however it is important the adequacy of maintaining the protein metabolism indicated by net protein ratio. During the experiment, animals fed on Pereskia aculeata gained less weight when compared with animals fed on casein, mean weekly feed consumption was also low. And it is a good protein source good quality due to present few limiting essential amino acids and thus are able to meet the needs for the diet in humans.

\section{Introduction}

Non-conventional vegetables are food alternatives due to their significant nutritional value in macro- and micro-nutrients, and easy dissemination (Rocha et al., 2008). Pereskia aculeata, a vegetable of the family Cactacea and sub-family Pereskioidae, is commonly known in Brazil by the name of ora-pro-nobis, (Lat. pray-for-us) or poor man's meat, due to its high protein rates (Almeida \& Corrêa, 2012).

The vegetable's leaves are rich in essential amino acids, minerals (calcium, magnesium, manganese and zinc) and vitamins ( $\mathrm{A}, \mathrm{C}$ and folic acid), and it is a supplementary nutrient sources in the diet of many Brazilians. Lack of toxicity and high diversity of nutrients make it extremely useful in human and animal diets (Almeida \& Corrêa, 2012; Takeiti et al., 2009). However, agronomic studies on the species are still rare but it may be underscored that the species averages $20 \%$ protein, with $85 \%$ digestibility, and high levels of essential amino acids, mainly lysine, leucine and tryptophan and thus it may prevent protein undernutrition (Mazia, 2012; Rocha et al., 2008).

Proteins may be classified according to their nutrition quality, detecting changes in nutritional value and contributing towards an assessment of nitrogen and amino acid requirements for growth and preservation of life (Henriques et al., 2008).

Digestibility conditions food's protein quality since it demonstrates the amount of proteins which are hydrolyzed by digestive enzymes and the amount absorbed by the organism as amino acids. Therefore, when peptide bonds are not hydrolyzed within the digestive process, part of the protein is excreted in the feces or metabolized by microorganisms of the large intestine (Mendes et al., 2007).

A protein's amino acid composition is compared to a standard reference and, consequently, the amino acids' chemical score (CS). The latter is a fast, consistent and low-cost technique which assesses amino acid contents in a protein source, and compares its rates with another reference for children within the 2-5-year-old bracket (Lee et al., 2016).

Consequently, the food and pharmaceutical industries have shown great interests in the genus Pereskia due to its high protein, good digestibility, fiber and mineral (iron and calcium) rates (Almeida \& Corrêa, 2012). 
Since data on the species's biology are rare, current analysis determines its in vivo digestibility, protein efficiency coefficient (PEC), net protein ratio (NPR), amino acid rate and the chemical score (CS) of amino acids of proteins of Pereskia aculeata. Protein digestibility corrected amino acid score (PDCAAS) method was applied. It consists of the product of chemical score of the limiting amino acid multiplied by the protein's true digestibility. The method is highly employed to evaluate protein quality since the procedure combines chemical and biological methods.

\section{Materials and methods}

\subsection{Preparation of samples}

Vegetal material of Pereskia aculeata Mill. was collected in Curitiba PR Brazil (25³8'29.28”S \& 49²9'61.47”W). Dry samples of the species were deposited in the herbarium of the Universidade Federal do Paraná (UFPR) under UPCB 75848. Leaves were duly washed thrice in distilled water and placed in a buffer at $60{ }^{\circ} \mathrm{C}$ for 24 hours; they were then ground and stored in a freezer at $-5{ }^{\circ} \mathrm{C}$ for later analysis.

\subsection{Chemical analyses}

Chemical analyses were performed in the Laboratory of Non-woody Products of Embrapa Florestas in Colombo PR Brazil, following official methodologies of the Association of Official Analytical Chemists (2000); data were given in \%, humid and dry base $\left(\mathrm{g} 100 \mathrm{~g}^{-1}\right)$. Analyses were done in triplicate and each datum is the average of three replications. Gravimetric method was employed to determinate dry matter rates: samples were dried in a buffer at $105^{\circ} \mathrm{C}$ till constant weight. Total nitrogen rate was determined by micro-Kjeldahl method and protein rate was calculated by multiplying total $\mathrm{N}$ by 3.99. Lipids were determined by continuous extraction with ethyl ether in Sohxlet apparatus at $45-50{ }^{\circ} \mathrm{C}$ for approximately 8 hours. The solvent was recovered and recipients with ether extract were cooled in a dryer and weighed. Lipid rates were obtained by gravimetric difference. Ash percentage was determined by carbonization and incineration of samples in an oven at $550{ }^{\circ} \mathrm{C}$ for approximately 4 hours. Concentration of food fiber was determined by the enzyme-gravimetric method, or rather, by enzyme digestion of the de-fatted sample with thermostable $\alpha$-amylase, amyglucosidase and protease to remove starch and protein contaminants. Soluble fraction was precipitated with ethanol $98 \%(v / v)$ and filtration. Precipitate and residue were washed in increasing concentrations of ethanol (78\% and 98\%) and acetone; they were then dried and weighed. Carbohydrates were obtained by the difference between total fraction and protein, moisture, ash and fiber percentages.

\subsection{Biological assay with rats}

The biological assay was conducted at the laboratory of animal experimentation of the Department of Pharmacology of the Universidade Federal do Paraná (UFPR) in Curitiba PR Brazil.

Experimental diets were prepared with formulas proposed by the American Institute of Nutrition (AIN-93), maintaining isoprotein and isoenergy characteristics. Diet components were acquired separately and dispensed in the laboratory till the saline and vitamin pre-mixture formulae were obtained. Casein, starch and choline bitartrate, weighed and mixed in a stainless steel blender, were added

Casein diet (standard), aprotaic diet and test diet based on leaf flour of Pereskia aculeata as protein source were prepared (Table 1).

\subsection{Animals}

Eighteen male white Wistar rats (Rattus norvegicus), average weight $61 \mathrm{~g}$, were distributed in 3 experimental groups with six animals each so that protein quality of diets formulated with Pereskia aculeata leaf flour was evaluated. The rats were individually penned in stainless steel and semi-metabolic cages for 28 days in a conditioned room of the Universidade Federal do Paraná.

Groups were divided according to Table 1: the first group was fed on control diet with standard protein (casein); the second group received aprotaic diet; the third group was fed on experimental diet based on the protein of flour of Pereskia aculeate leaves.

\subsection{Evaluation methods for protein quality}

\section{Determination of true digestibility}

True digestibility was detected by an assay in which diets were stained with carmine indigo at a concentration of

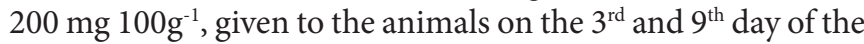
experiment. Feces were collected in individual troughs between the $4^{\text {th }}$ and $10^{\text {th }}$ day. They were then dried in a forced air buffer at $105^{\circ} \mathrm{C}$ for 24 hours, weighed and ground to determine nitrogen concentration.

True digestibility (TD) was thereby calculated by determining the amount of nitrogen ingested in the diet, excreted in the feces and metabolic fecal loss estimated by the amount of nitrogen excreted by the animals fed on diet with low protein rate (APT). True digestibility was calculated by the following formula: \%Digestibility $=\mathrm{I}-(\mathrm{F}-\mathrm{FO}) \times 100$, where $\mathrm{I}=$ nitrogen ingested by test group (COG); $\mathrm{F}=$ fecal nitrogen of the test group $(\mathrm{COG}) ; \mathrm{FO}=$ fecal nitrogen of the group fed on diet with very low protein rate (APT).

Table 1. Composition of semi-purified diets in the experiment: casein control diet (CAS), low protein rate (APT) and diet based on Pereskia aculeata (PKS).

\begin{tabular}{cccc}
\hline Ingredients (g/100 g diet) & \multicolumn{3}{c}{ Diets } \\
\cline { 2 - 4 } & CAS & APT & PKS \\
\hline Casein (81.3\% protein) & 13.21 & - & - \\
Pereskia aculeata (21.56\% protein) & - & - & 48.70 \\
Saline mixture & 3.50 & 3.50 & 3.50 \\
Vitamin mixture & 1.00 & 1.00 & 1.00 \\
Choline bitartrate & 0.20 & 0.20 & 0.20 \\
Vegetal oil (soybean oil) & 5.00 & 5.00 & 5.00 \\
Corn starch & 77.09 & 90.30 & 41.60 \\
$\%$ proteins & 10.74 & - & 10.49 \\
\hline
\end{tabular}




\section{Protein Efficiency Quotient $(Q E P=P E Q)$}

Recommendations by the Association of Official Analytical Chemists (2000) were the quality standards in the preparation of diets to assess protein quality. The Protein Efficiency Quotient (PEQ) was employed, or rather, the quotient between animals' weight gain and the amount of protein ingested, calculated during 28 days by [weight gain of the test group ( $\mathrm{g}$ ) / protein taken by the test group $(\mathrm{g})]$.

\section{Net Protein Ratio $(R P L=N P R)$}

Net Protein Ratio (NPR), a modification of PEQ, is the sum of the weight gain of the test group and weight loss of the aproteic group, according to the formula: [weight gain of test group (g) + weight loss of aproteic group (g)/protein ingested by test group]. The ratio between weight gain of the animals (g) and total intake of diets $(\mathrm{g})$ at the end of the experiment was determined, or rather, feed efficiency.

\section{Analysis of amino acids in hydrolyzed acid}

After leaf extraction by continuous reflow with ethanol $80 \%$ and the evaporation of the solvent at $40{ }^{\circ} \mathrm{C}$, the samples were hydrolyzed with bi-distilled hydrochloric acid $(\mathrm{HCl}) 6 \mathrm{~N}$, followed by pre-column derivation of free amino acids with phenyl isothiocyanate (PITC). Further, phenylthiocarbamyl amino acid (PTC-aa) derivatives were separated in reverse phase column C18 (Pico-Tag $3.9 \times 150 \mathrm{~mm}$ ) with monitoring at wave length $254 \mathrm{~nm}$. Samples were quantified by measuring peak areas according to the appearance of each amino acid, and compared to peak area of an amino acid standard with known concentration (control) derived from the same experimental conditions and within the same time as test samples. Chemical score corrected by digestibility was calculated by equation: PDCAAS = lowest essential amino acid score $\mathrm{x}$ true digestibility of the protein. PDCAAS scores greater than one unit indicated good quality protein.

\section{Determination of protein digestibility corrected amino acid score (PDCAAS)}

PDCAAS was calculated by determining nitrogen, protein, essential amino acids, amino acid scores and true digestibility rates.
The chemical score of the most limiting essential amino acid from each protein source was selected and PDCAAS was calculated by multiplying the lowest score of the essential amino acid by the digestibility of the protein. Good quality protein contained PDCAAS equal to or higher than 1.0

\section{Statistical design}

Analysis of variance (one-way ANOVA) determined $\mathrm{F}$ rate. Tukey's test at $5 \%$ probability was employed to compare averages.

\section{Results and discussion}

The chemical composition of casein and aproteic diets and diet made from flour of Pereskia aculeata leaves shows no significant difference for ash, lipids and calories. However, diet based on Pereskia aculeata had lowest humidity and fiber rate when compared with the others (Table 2).

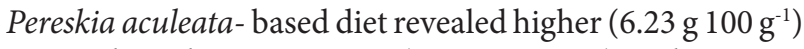

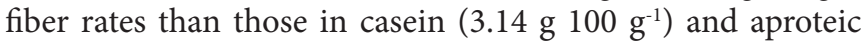

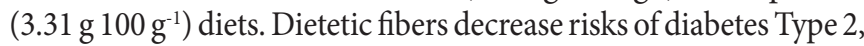
cardiovascular diseases and colon cancer by reducing digestion and absorption of macronutrients (Kaczmarczyk et al., 2012). In fact, diet fiber is beneficent to reduce body weight and arterial pressure and to prevent diabetes (Bernaud \& Rodrigues, 2013).

High protein levels do not necessarily indicate that food is a high biological source since protein quality also depends on amino acids and digestibility. The amount of protein and non-protein nitrogen should also be assessed (Chater et al., 2015). Consequently, the protein rate of a specific diet is calculated by its essential amino acids and its biological result depends on the protein's digestibility (Alves et al., 2008).

Protein quality classifies proteins according to their nutrition potential to evaluate nitrogen and amino acids requirements available for the growth and maintenance of life (Henriques et al., 2008). The flour of Pereskia aculeata leaves provided approximately

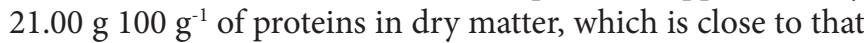

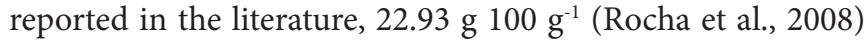

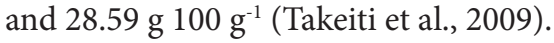

Aproteic diet had the lowest protein rates $\left(0.90{\left.\mathrm{~g} 100 \mathrm{~g}^{-1}\right)}^{-1}\right.$

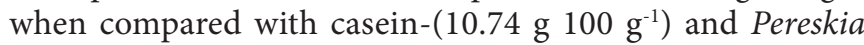

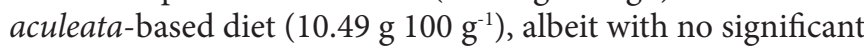
difference.

Table 2. Analysis of the chemical composition of diets used in current experiment: control diet with casein (CAS), diet with low protein rate $(\mathrm{APT})^{1}$ and diet based on Pereskia aculeata protein $(\mathrm{PKS})^{2,3,4}$.

\begin{tabular}{|c|c|c|c|c|c|c|c|}
\hline \multirow{2}{*}{ Experimental diets } & Humidity & Ashes & Lipids & Proteins & Fiber & NiFExt & Calories \\
\hline & \multicolumn{6}{|c|}{ 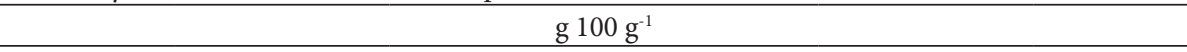 } & kcal \\
\hline CAS & 7.12 & 3.81 & 7.22 & 10.74 & 3.14 & 67.97 & 379.82 \\
\hline Standard deviation & $1.06 \mathrm{a}$ & $0.61 \mathrm{a}$ & $1.68 \mathrm{a}$ & $1.30 \mathrm{a}$ & $0.79 \mathrm{a}$ & $4.11 \mathrm{a}$ & $26.27 \mathrm{a}$ \\
\hline PKS & 5.65 & 3.14 & 7.59 & 10.49 & 6.23 & 66.90 & 377.87 \\
\hline Standard deviation & $1.16 \mathrm{~b}$ & $0.53 \mathrm{a}$ & $1.40 \mathrm{a}$ & $1.56 \mathrm{a}$ & $1.09 \mathrm{~b}$ & $3.43 \mathrm{a}$ & $32.11 \mathrm{a}$ \\
\hline APT & 6.88 & 3.69 & 7.41 & 0.90 & 3.31 & 77.81 & 381.53 \\
\hline Standard deviation & $1.09 \mathrm{a}$ & $0.50 \mathrm{a}$ & $1.53 \mathrm{a}$ & $0.09 \mathrm{~b}$ & $0.85 \mathrm{a}$ & $3.81 \mathrm{~b}$ & $23.15 \mathrm{a}$ \\
\hline
\end{tabular}

${ }^{1}$ Aproteic diet by RPL calculations; ${ }^{2}$ Rates given in the table are means of 5 replications of each analysis; ${ }^{3}$ For the conversion of nitrogen into protein (N:P) of the PKS group, the factor

3.99 was employed, following Association of Official Analytical Chemists (2000); ${ }^{4}$ Different letters in the column show significant difference at $p<0.05$ level. 
The inclusion of high quality vegetal proteins in diets for humans is crucial, especially for strict vegetarians since they must obtain proteins from cereals, legumes and grains. Although proteins in such diets are supplemented, insufficient concentrations of essential amino acids may cause 'hidden' malnutrition which is difficult to diagnose (Alves et al., 2008).

The biological assay comprised weight gain (g) by estimating animals' feed consumption (g) (Table 3), feed efficiency, protein quality indexes, Protein Efficiency Quotient (PEQ), Net Protein Ratio (NPR) and True Digestibility (TD) rates (Table 4), derived from the experimental diets with chemical composition described in Table 1.

There was no significant difference in the initial animal weight for the three diet groups since no difference was above $0.50 \mathrm{~g}$. However, during the experiment, the animals of control group (CAS) had a significant increase in body weight. Further, the animals of the group fed on diet based on Pereskia aculeata (PKS) also increased in weight but at a lower rate when compared to the CAS group (Table 3). On the other hand, the aproteic group had a constant weight loss till the $14^{\text {th }}$ day of the experiment.

Wistar rats fed on Pereskia grandiflora protein decreased body weight as from the second week of the experiment and the control group (CAS) had a weight increase (Almeida et al., 2014), disagreeing with results in current study. According to the same authors, a hypercalorie diet is more efficient to reduce body weight in Wistar rats when compared to a casein-based diet.

Weight gain in Wistar rats of the PKS group reached $27.83 \mathrm{~g}$ on the $14^{\text {th }}$ day and $34.67 \mathrm{~g}$ on the $28^{\text {th }}$ day, whereas CAS animals had a weight gain of $78.00 \mathrm{~g}\left(14^{\text {th }}\right.$ day) and $128.43\left(28^{\text {th }}\right.$ day $)$ (Table 3). Contrastingly to these results, female Holtzamn rats fed on Pereskia aculeata leaves flour decreased $3.40 \mathrm{~g}$ (Pinto et al., 2015). It should be underscored that at the period of the experiment semi-purified diets did not contain important growth factors and these may have affected experimental results.

Since animals fed on Pereskia aculeata gained less weight when compared with animals fed on casein, mean weekly feed consumption was also low (Table 3). Marinelli (2016) found a
$22.50 \%$ increase in weight gain in the group of animals treated with Pereskia aculeata flour when compared to the control group, a fact that can be explained by the fact that the feed added of the flour of Pereskia aculeata has a higher energy than the control ration.

The animals, fed on Pereskia aculeata, rich in fibers (56.85\%), had low feed ingestion, probably due to taste, since one of the main effects of fiber-rich diets is increase in satiety and, therefore, decrease in appetite (Pinto et al., 2015; Fuller et al., 2016).

Animals' weight gain and protein amounts consumed by the end of the experiment (28 days) affected PEQ. It reached 1.37 in a $1-5$ scale, or rather, only $26 \%$ of the expected development, when compared to casein-based performance (Table 4). The scale reveals that for each gram of ingested Pereskia aculeata protein, a weight increase of $1.32 \mathrm{~g}$ may be obtained. However, the above rate is lower than that obtained for standard diet (CAS), with an increase of $4.86 \mathrm{~g}$.

In their studies on different sources of proteins, Mendes et al. (2009) reported that highest PEQ and NPR rates occurred in animal-derived proteins, with highest PEQ in broiler meat (4.29) and lowest rate in soybean (1.78), whilst NPR rates were highest for broiler meat (4.76) and lowest for soybean (2.64). When the above results were compared to those in current assay, Pereskia aculeata diet had similar rates as that in soybean, with 1.37 for PEQ and 2.87 for NPR.

In the case of NPR, the difference between treatments decreased: Pereskia aculeata protein proved to be efficient for the maintenance of protein turnover rather than growth since Pereskia-based diet amounted to $56 \%$ of rate obtained in CAS. The above may be due to the fact that PEQ failed to comprise maintenance and revealed protein used for growth, whereas NPR comprised protein for the animals' metabolic maintenance (Henriques et al., 2008).

Digestibility, a determining factor in protein quality, is significantly lower in Pereskia aculeata diet when compared to CAS, respectively with $68.22 \%$ and $96.17 \%$ (Table 4 ). Digestibility measures the percentage of proteins hydrolyzed

Table 3. Weight evolution and feed ingestion of recently-weaned rats fed on standard diet with casein (CAS), diet with low protein rate (APT) and diet based on Pereskia aculeata protein (PKS)*.

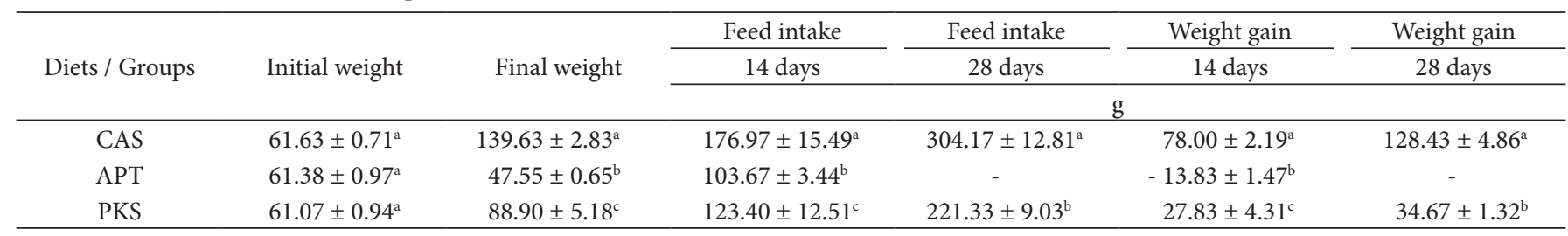

${ }^{*}$ Different letters in each column indicate significant difference at $\mathrm{p}<0.05$.

Table 4. Food efficiency, protein efficiency quotient (PEQ and RPEQ), net protein ratio (NPR and RNPR) and true digestibility (TD) of Pereskia aculeata proteins (PKS) in weaned rats (21 days), with casein (CAS) as reference.

\begin{tabular}{|c|c|c|c|c|c|c|}
\hline \multirow{2}{*}{ Diets } & Food Efficiency ${ }^{* *}$ & \multirow{2}{*}{ PEQ } & RPEQ & \multirow{2}{*}{ NPR } & RNPR & $\mathrm{TD}$ \\
\hline & $\%$ & & $\%$ & & $\%$ & $\%$ \\
\hline $\mathrm{CAS}^{*}$ & $42.09 \pm 0.74^{\mathrm{a}}$ & $3.92 \pm 0.07^{a}$ & 100 & $4.98 \pm 0.23^{\mathrm{a}}$ & 100 & $96.17 \pm 0.16^{\mathrm{a}}$ \\
\hline PKS & $14.39 \pm 1.65^{\mathrm{b}}$ & $1.37 \pm 0.16^{\mathrm{b}}$ & $26.57 \pm 2.48$ & $2.87 \pm 0.19^{b}$ & $43.60 \pm 3.53$ & $68.22 \pm 1.28^{\mathrm{b}}$ \\
\hline
\end{tabular}

${ }^{\star}$ Different letters in each column indicates significant difference $(p<0.05) ;{ }^{* \star}$ All data comprise average and standard deviation. 
by digestive enzymes and absorbed in the form of amino acids or any other nitrogen compounds (Hiane et al., 2006).

Digestibility rate of Pereskia-based diet is low when compared to animal-derived proteins since most have good digestibility, or rather, they are efficient in the absorption of amino acids (Hiane et al., 2006). In fact, digestibility is an important factor which defines the proteins' nutritional quality (Pompeu et al., 2014).

Mendes et al. (2009) studied the protein quality of several foods and reported that soybean had the lowest digestibility rate with $78.05 \%$, whereas that of rice, broiler meat, fish and pork lay between 92 and $93 \%$, while digestibility of oats and quinoa was respectively $87.84 \%$ and $85.95 \%$.

Results show that digestibility of vegetal products is lower than that of animal-derived products due to the former having a higher concentration of anti-nutrition factors, such as tannins and protease inhibitors, which decrease digestibility. However, the digestibility in vegetal sources may have been underestimated since fermentable fibers increase the activity of intestine flora and thus the amount of endogen nitrogen in feces (Mendes et al., 2009).

A good quality protein mixture provides good digestibility and adequate proportions of total nitrogen and essential amino acids, not synthesized by the organism (Boye et al., 2012).

The composition of the amino acids of the Pereskia aculeata sample and reference standard for essential amino acids recommended by FAO/WHO (Food and Agriculture Organization, 2013) for 2-5-year-old children were compared. Results indicate that tryptophan (0.46) was the limiting amino acid (Table 5).

Flour from Pereskia aculeata leaves proved to be a good source of histidine, lysine and methionine + cystine for 2-5-year-old children. In fact, rates were higher than those recommended by FAO (Food and Agriculture Organization, 2013). Leucine and threonine proved to be a good source since rates were above score 1 (Table 5).

Although cereal proteins have usually low nutritional quality, with lysine as its first limiting amino acid, quinoa is an exception since it failed to reveal any limiting essential amino acid, different from results in current assay (Alves et al., 2008).

Chemical score corrected by protein digestibility (PDCAAS) was determined only for the limiting amino acid tryptophan, with $35.20 \%$ (Table 5).

Flour of Pereskia aculeata leaves had an incompatible performance with high biological rate proteins when assessed by true digestibility, with less than $80 \%$. Its PDCAAS proved to be a good quality protein source and it may provide human diet requirements when adequately supplemented (Alves et al., 2008).

Animal-derived proteins have a good digestibility (over 95\%), whereas vegetal-derived ones are lower than $80 \%$ (Calheiros \& Canniatti-Brazaca, 2011).

True digestibility of several types of animal-derived food such as eggs (97\%), milk (97\%), beef (97\%) and liver (98\%) is high and, consequently, they feature excellent protein quality, in contrast to digestibility of the flour from Pereskia aculeata
Table 5. PDCAAS of Pereskia aculeate protein.

\begin{tabular}{ccccc}
\hline Essential amino acid & $\begin{array}{c}\mathrm{mg} \mathrm{g}^{-1} \\
\text { protein }\end{array}$ & $\begin{array}{c}\text { FAO/WHO } \\
\text { standard }\end{array}$ & $\begin{array}{c}\text { Amino } \\
\text { acid score }\end{array}$ & PDCAAS \\
\hline Phenylalanine + & 84.42 & 63 & 1.34 & \\
Tyrosine & & & 0.85 & \\
Histidine & 16.23 & 19 & 1.46 & \\
Isoleucine & 40.87 & 28 & 1.00 & \\
Leucine & 66.32 & 66 & 0.72 & \\
Lysine & 41.74 & 58 & 0.89 & \\
Methionine + Cystine & 22.26 & 25 & 0.452 \\
Threonine & 36.64 & 34 & 1.43 & \\
Tryptophan & 5.10 & 11 & 35 & \\
Valine & 50.09 & &
\end{tabular}

leaves. However, the digestibility of vegetable-derived food, such as corn $(76 \%)$, wheat $(79 \%)$, oats $(76 \%)$, rice $(75 \%)$, soybean $(78 \%)$ and beans $(60 \%)$, is similar to that reported in current assay (Alves et al., 2008).

\section{Conclusions}

One may conclude that, within the conditions of current assay, flour produced from the leaves and stem of Pereskia aculeata may not be adequate to warrant satisfactory growth levels when provided in the diet as a single protein source. However, one must also consider its fitness in the maintenance of protein metabolism in the organism indicated by NPR. When its PDCAAS is calculated, tryptophan's significant limitation causes unsatisfactory yield of the protein indexes NPR and PEQ when compared to casein standard. However, due to few limiting factors, it may be targeted for protein supplementation with other vegetal sources and thus it may provide for the protein needs in human diets

\section{References}

Almeida, M. E. F., \& Corrêa, A. D. (2012). Utilização de cactáceas do gênero Pereskia na alimentação humana em um município de Minas Gerais. Ciência Rural, 42(4), 751-756. http://dx.doi.org/10.1590/ S0103-84782012000400029.

Almeida, M. E. F., Junqueira, A. M. B., Simão, A. A., \& Corrêa, A. D. (2014). Caracterização química das hortaliças não-convencionais conhecidas como ora-pro-nobis. Bioscience Journal, 30(1), 431-439.

Alves, L. F., Rocha, M. S., \& Gomes, C. C. F. (2008). Avaliação da qualidade proteica da Quinua Real (Chenopodium quinua Willd) através de métodos biológicos. e-Scientia, 1(1), 1-16.

Association of Official Analytical Chemists - AOAC. (2000). Official Methods of Analysis (17th ed.). Gaithersburg: AOAC.

Bernaud, F. S. R., \& Rodrigues, T. C. (2013). Fibra alimentar: ingestão adequada e efeitos sobre a saúde do metabolismo. Arquivos Brasileiros de Endocrinologia e Metabologia, 57(6), 397-405. PMid:24030179. http://dx.doi.org/10.1590/S0004-27302013000600001.

Boye, J., Wijesinha-Bettoni, R., \& Burlingame, B. (2012). Protein quality evaluation twenty years after the introduction of the protein digestibility corrected amino acid score method. British Journal of 
Nutrition, 108(Suppl 2), S183-S211. PMid:23107529. http://dx.doi. org/10.1017/S0007114512002309.

Calheiros, K. O., \& Canniatti-Brazaca, S. G. (2011). Disponibilidade de ferro, digestibilidade de proteína e teor de $\beta$-caroteno em formulados alternativos de baixo custo para alimentação enteral de idosos. Ciência e Tecnologia de Alimentos, 31(1), 41-55. http://dx.doi.org/10.1590/ S0101-20612011000100006.

Chater, P., Wilcox, M. D., Pearson, J. P., \& Brownlee, I. A. (2015). The impact of dietary fibres on the physiological processes governing small intestinal digestive processes. Bioactive Carbohydrates and Dietary Fibre, 6(2), 117-132. http://dx.doi.org/10.1016/j.bcdf.2015.09.002.

Food and Agriculture Organization - FAO. World Health Organization - WHO. (2013). Dietary protein quality evaluation in human nutrition (Report of and FAO expert consultation). Rome: FAO.

Fuller, S., Beck, E., Salman, H., \& Tapsell, L. (2016). New Horizons for the Study of Dietary Fiber and Health: A Review. Plant Foods for Human Nutrition, 71(1), 1-12. PMid:26847187. http://dx.doi. org/10.1007/s11130-016-0529-6.

Henriques, G. S., Simeone, M. L. F., \& Amazonas, M. A. L. (2008). Avaliação in vivo da qualidade proteica do champignon do Brasil (Agaricus brasiliensis Wasser et al.). Revista de Nutrição, 21(5), 535-543. http://dx.doi.org/10.1590/S1415-52732008000500006.

Hiane, P. A., Macedo, M. L. R., Silva, G. M., \& Braga Neto, J. A. (2006). Avaliação Nutricional da proteína de amêndoas de bocaiúva, Acrocomia aculeata (Jacq.) Lodd., em ratos Wistar em crescimento. Boletim do Centro de Pesquisa e Processamento de Alimentos, 24(1), 191-206.

Kaczmarczyk, M. M., Miller, M. J., \& Freund, G. G. (2012). The health benefits of dietary fiber: beyond the usual suspects of type 2, cardiovascular disease and colon cancer. Metabolism: Clinical and Experimental, 61(8), 1058-1066. PMid:22401879. http://dx.doi. org/10.1016/j.metabol.2012.01.017.

Lee, W. T., Weisell, R., Albert, J., Tomé, D., Kurpad, A. V., \& Uauy, R. (2016). Research Approaches and Methods for Evaluating the Protein Quality of Human Foods Proposed by an FAO Expert Working Group in 2014. The Journal of Nutrition, 146(5), 929-932. PMid:27052532. http://dx.doi.org/10.3945/jn.115.222109.
Marinelli, P. S. (2016) Farinhas de moringa (Moringa oleifera Lam.) e ora-pro-nobis (Pereskia aculeata Mill.): Biomateriais Funcionais (Tese de doutorado). Universidade Estadual Paulista "Julio de Mesquita Filho", Bauru.

Mazia, R. S. (2012). Influência do tipo de solo usado para o cultivo de Pereskia aculeata sobre propriedade proteica. Revista Saúde e Pesquisa, 5(1), 59-65.

Mendes, F. Q., Oliveira, M. G. A., Cardoso, L. R., Costa, N. M. B., \& Sant'Ana, R. C. O. (2007). Digestibilidade proteica e caracterização bromatológica de linhagens de soja com ausência ou presença do inibidor de tripsina kunitz e das isozimas lipoxigenases. Bioscience Journal, 23(1), 14-21.

Mendes, F. Q., Oliveira, M. G. A., Costa, N. M. B., Pires, C. V., \& Hoffmam, Z. B. (2009). Qualidade proteica de diversos alimentos, incluindo diferentes variedades de soja. Alimentos e Nutrição, 20(1), 77-86.

Pinto, N. C. C., Duque, A. P. N., Pacheco, N. R., Mendes, R. F., Motta, E. V. S., Bellozi, P. M. Q., Ribeiro, A., Salvador, M. J., \& Scio, E. (2015). Pereskia aculeata: a plant food with antinociceptive activity. Pharmaceutical Biology, 53(12), 1780-1785. PMid:26084799. http:// dx.doi.org/10.3109/13880209.2015.1008144.

Pompeu, D. G., Carvalho, A. D. S., Costa, O. F., Galdino, A. S., Bonoto, D. G., Silva, J. A., \& Granjeiro, P. A. (2014). Fatores antinutricionais e digestibilidade "in vitro" de folhas de Pereskia aculeata Miller. Biochemistry and Biotechnology Reports, 3(1), 1-9. PMid:28626641. http://dx.doi.org/10.5433/2316-5200.2014v3n1p1.

Rocha, D. R. C., Pereira-Júnior, G. A., Vieira, G., Pantoja, L., Santos, A. S., \& Pinto, N. A. V. D. (2008). Macarrão adicionado de Ora-pronobis (Pereskia aculeata Miller) desidratado. Alimentos e Nutrição, 19(4), 459-465.

Takeiti, C. Y., Antonio, G. C., Motta, E. M., Collares-Queiroz, F. P., \& Park, K. J. (2009). Nutritive evaluation of non-conventional leafy vegetable (Pereskia aculeata Miller). International Journal of Food Sciences and Nutrition, 60(1, Suppl 1), 148-160. PMid:19468927. http://dx.doi.org/10.1080/09637480802534509. 